\title{
The Rights of Passengers in the Event of Death and Personal Injury on Board a Cruise Ship Under the 1974 Athens Convention and its 2002 Protocol - the Implementation of the Convention and The 2002 Protocol
}

\author{
Srđan Vujičić, Branka Milošević-Pujo, Veronika Gašpar
}

The rights of cruise ship passengers in the event of death and personal injury are dependent upon conditions under which carriers are liable and the extent of their liability. The development of the cruise industry necessitated the establishment of a regime of liability for loss suffered by passengers during voyage, that has been regulated by the Athens Convention and its 2002 Protocol. In the very beginnings of the cruise industry, transportation standards were much lower than today, with less attention paid to the needs of the passengers in terms of safety and legal standing. When the SOLAS Convention entered into force, a

\section{KEY WORDS}

$\sim$ Passenger rights

$\sim$ Cruise ship

$\sim$ Athens Convention

$\sim$ PAL PROT 2002

$\sim$ Regulation 392/2009

2006 IMO Reservation and Guidelines

$\sim$ Directive 90/314

Directive 2015/2302

University of Dubrovnik, Maritime Department, Dubrovnik, Croatia

e-mail: srdjan.vujicic@unidu.hr

doi: 10.7225/toms.v10.n01.022

This work is licensed under (cc) BY

Received on: Jan 7, 2021 / Revised on: Mar 5, 2021 / Accepted on: Apr 9, 2021 / Published: Apr 20, 2021 number of safety standards were designed to ensure passenger protection and safety, while the Athens Convention regulated and harmonized the legal status of passengers. Various other organizations also made a great contribution in this respect. In addition to the above, Regulation (EC) No 392/2009, the 2006 IMO Reservation and Guidelines, Directive 90/314/EEC and Directive (EU) $2015 / 2302$, which contributed to the legal protection of passengers, need be mentioned.

The rights granted under the Athens Convention will be compared with EU regulations and directives. The ratification process, the most important provisions, the progress achieved through the application of the Convention and the implementation process will be analysed. The development strategy and SWOT analysis can assist states with their decision on the ratification of the Convention and its Protocol. The aim is to draw conclusions about the legal effects of the implementation of the Convention in member states, based on a comprehensive analysis, and to provide passengers with information on their rights in international carriage.

\section{INTRODUCTION}

The safety and protection of passengers and crew on board ships are crucial elements for ship operators or carriers. ${ }^{1}$

1. Carrier means a natural or legal person, other than a tour operator, travel agent or ticket vendor, offering transport by passenger services or cruises to the general public; 
This paper focuses on the regulation of passenger rights on cruise ships, carrier liability, the importance of IMO Reservations and the adoption of the 2002 Athens Convention Protocol (PAL PROT). In addition, the relationship between PAL PROT 2002 and EU legislation Directive 2015/2302 will be analysed. However, the main terminology must first be defined.

In a broader sense, passenger ship cruising is characterized by the comfort of traveling between ports on board specialized passenger ships, high quality of service and unforgettable experience. In a narrower sense, it implies the departure of passengers on a safe journey on a passenger ship, and a happy and satisfied return home. Cruising is an activity that involves the transport of people by special passenger ships according to a pre-planned sailing schedule, offering various sports and leisure activities for the purpose of relaxation, entertainment and recreation (Šamanović, 2002). Moreover, Regulation (EU) No $1177 / 2010$ defines cruise as transport service by sea or inland waterway, operated exclusively for the purpose of pleasure or recreation, supplemented by accommodation and other facilities, exceeding two overnight stays on board.

According to Council Directive 90/314/EEC (Atlija, 2016) Package travel means the pre-arranged combination of not fewer than two of the following: transportation, accommodation and other tourist services when sold or offered for sale at an inclusive price and when the service covers a period of more than twentyfour hours or includes overnight accommodation. An extended definition was given in Directive (EU) 2015/2302 and grants passengers better legal protection. However, the definitions of cruising and package traveling are by nature synonymous in EU legislation and cruising contracts. Furthermore, the above Directive gives a definition of organiser ${ }^{2}$ who is responsible for any issues regarding package travel contracts. ${ }^{3}$

The International Maritime Organization $\left(\mathrm{IMO}^{4}\right)$ has adopted a number of conventions and rules to improve passenger safety on board ships. International Convention for the Safety of Life at Sea (SOLAS 1974 )5 defines "passenger" as every person other than the master and the members of the crew or other persons employed or engaged in any capacity on board a ship on the business of the ship, and a child under one year of age.

2. Organiser as per EU Directive 2015/2302 means a trader who combines and sells or offers for sale packages, either directly or through another trader or together with another trader, or the trader who transmits the traveller's data to another trader

3. Package travel contract as per EU Directive 2015/2302 means a contract on the package as a whole or, if the package is provided under separate contracts, all contracts covering travel services included in the package

4. United Nations specialized agency with responsibility for the safety and security of shipping and the prevention of marine and atmospheric pollution by ships. IMO's work supports the UN sustainable development goals. IMO currently has 174 Member States and three Associate Members (Macao, Hong Kong, Faroes)

5. The Convention specifies minimum standards for the construction, equipment and operation of ships, compatible with their safety.
In spite of the current health and financial crisis, cruise ships sitting idly due to the pandemic (COVID-19), shipping accidents (Costa Concordia, Sea Diamond, Sewol) and frequent pirate and terrorist attacks ${ }^{6}$, the interest in this form of travel is still great. According to (Ward, D. 2018) there are 75 passenger companies on the market, with a total of 350 ocean-going ships. The issue of Seatrade Cruise Review from September 2020 (2020a), reports that 339 ships are used for ocean cruising activities. The number does not include laid up ships, ships for sale, regular passenger traffic, coastal/river cruising vessels. An estimated 109 new builds of varying deadweight tonnages and up to $227,000 \mathrm{GT}^{7}$ have been ordered and are scheduled for delivery by 2027 , as well as 222,152 lower berths (Seatrade, 2020). Until the COVID-19 outbreak, the industry experienced continuous growth in the number of passengers, and constituted a significant segment in the general economy and tourism industry. This is confirmed by the CLIA ${ }^{8}$ cruise industry outlook which states that while there were 17.8 million passengers in 2009, 30 million were expected to cruise in 2019, which is an increase of about 12.2 million passengers in a decade (CLIA, 2019). According to CLIA, passengers from North America were by far the most numerous passengers in 2018, accounting for approximately $50 \%$ of all passengers worldwide. They were followed by travellers from Western Europe, with half of the American share, with Asia coming in third. Other passengers came from Australia, New Zealand and the Pacific, South America, Scandinavia and Iceland, Eastern Europe, and other regions, whose shares are extremely small compared to the top three regions. A mix of cultures and nationalities implies that no one region has impact on the development of this industry.

In general, the cruise industry development and the use of its services depend on passenger demand and a number of other factors, including:

- geopolitical position and stability of a certain geographical area;

- $\quad$ world economic situation (financial stability of passengers);

- exceptional circumstances at a particular geographical location and/or worldwide;

- $\quad$ transport price and supply ratio;

- $\quad$ personal and legal protection and safety of passengers.

Therefore, passenger transportation technology involves sustainable development as long as the above factors are

6. As per cruisecritic available from: https://www.cruisecritic.com/articles. $\mathrm{cfm}$ ?ID $=811$, in 2005, the Seaborne Spirit was attacked by machine guns 100 miles from the coast of Somalia; in 2008, pirates attacked the Le Ponant and the Oceania Nautica; in 2009, the MSC Melody experienced cruise ship pirate attack; in 2011, the Spirit of Adventure and in 2012, small boats approached the Azamara Journey.

7. Gross tonnage is based on "the molded volume of all enclosed spaces of the ship"

8. The Cruise Lines International Association; the world's largest cruise industry trade association, the leading authority of the global cruise community. The CLIA supports policies and practices that foster a safe, secure, healthy and sustainable cruise ship environment and is dedicated to promoting the cruise travel experience. 
acceptable to those who travel. One of the key factors that can be acted upon is the analysis and consolidation of international legal norms to ensure the safety of transportation users, i.e. passengers, with adequate measures. The historical development of passenger rights in EU legislation and under the Athens Convention was researched by Pospišil Miler, M (Pošpišil-Miler, 2014). The regulation of passenger rights and carrier liability for the carriage of passengers by sea within the EU and the implementation analysis of the Athens Convention in the context of the broader EU passenger rights initiative was in the focus of the research paper by Lamont-Blanc, S. (2018). Systematic accountability for package traveling in EU legislation within international voyage and carrier liability were researched by Atlija (2016). In this paper, authors analysed previous research, directives and conventions, and used SWOT analysis to assist the states with their decision on the ratification of the Convention and its Protocol. The paper focuses on the presentation of passenger rights and challenges to the readers.

\section{SAFETY STANDARDS PROTECTION AND PASSENGER RIGHTS UNDER PAL}

The fundamental tasks of the IMO conventions are: the improvement of the technical requirements for shipbuilders and shipowners, as well as of crewmember duties, to protect the passengers, the crew and the marine environment. Many travel companies joined the CLIA and adopted additional requirements prescribed by this organization. To ensure the commitment to the safety of passengers, the CLIA brought the Passenger Bill of Rights in 2013, adopted by the CEOs of member cruise lines and published on their websites ${ }^{9}$. The Vessel Sanitation Program $\left(V_{S P}^{10}\right)$ of the Centre for Disease Control and Prevention (CDC) assists the cruise ship industry with the prevention and control of the introduction, transmission, and spread of gastrointestinal (GI) illnesses on cruise ships. The CDC published the VSP Operations Manual for cruise ship owners and their crews to help them create a healthy environment for passengers and crew alike. The United States Public Health (USPH) standard was adopted by the USA, Canada, Australia, the United Kingdom and Brazil. All ships carrying American passengers are subject to at least two such standardized inspections each year. If restaurants or hotels ashore were subject to inspections based on USPH standards, $95 \%$ of them would fail to meet them (Ward, D. 2018.) According to the International Safety Management Code (ISM Code) every

9. The right to have this Cruise Industry Passenger Bill of Rights published on each line's website.

10. The VSP developed in order to achieve and maintain a level of sanitation (water sanitation, including free chlorine residuals in the potable water system, swimming pool, and hot tub filters and food sanitation) that would lower the risk of gastrointestinal disease outbreaks and assist the cruise industry to ensure a healthy environment for passengers and crew shipowner is required to ensure the safe management and operation of his ships in terms of maritime safety and protection of the marine environment. International inspections and audits are carried out. However, ship accidents still happen and the protection of passenger rights is crucial.

The Athens Convention (Athens Convention relating to the Carriage of Passengers and their Luggage by Sea (PAL) is the basic ${ }^{11}$ convention, strictly dealing with legal provisions, without addressing the other principles of ship operations. This convention regulates the legal relationship between carriers and passengers, defining their mutual rights and obligations. As stated, the general safety and protection of passenger health and lives, are the foundation of successful passenger transportation by sea.

The Athens Convention is applicable only to the international carriage of passengers and their luggage by sea. Moreover, it is necessary to define the place or port of departure and destination, a ship's flag state and state of registration, as well as the place of conclusion of the contract of carriage. In terms of its evolution, the Athens Convention was not significantly amended except with respect to the units of account and the limitation of liability. The most important provisions of the 2002 Protocol are the calculation of the limits of liability, the methods of liability exemption, and the certificate attesting that the compulsory insurance or other financial guarantee is in force, as shown in Table 1. All states that have consented to be bound by the PAL PROT 2002 are required to denounce their previous practices (PAL 74, 76, 90).

The main reasons for the amendment to the Athens Convention were a number of incidents showing that the existing amounts stated in the Convention were too low (Atlija, 2016). The carrier is exempted from liability if the incident resulted from an act of war, hostilities, insurrection, or a natural phenomenon of an exceptional, inevitable and irresistible character, or if the incident was wholly caused by a third party act or omission. An act of terrorism against passenger ships is problematic for carriers since the liability exemption is not applicable. In addition to the opposing viewpoints of countries on the limitation amounts (e.g. Japan and Norway consider the amounts too low, while countries like Korea and China consider them too high), the aforementioned changes regarding terrorism insurance will be an obstacle to the harmonization of laws. The International Chamber of Shipping (ICS), the International Council of Cruise Lines (ICCL), the International Group of P\&l Clubs and the International Union of Marine Insurance (IUMI) brought this issue to the forefront. To regulate the issue of the amount of liability limits, an opt-out clause was introduced, where everyone shall be entitled to set their individual amounts. The difference between

11. Internatiuonal Conventon on Travel Contracts (CCV), EU Directives, National legislations etc. 
Table 1.

Grounds for carrier liability under the Athens Convention and its protocols.

\begin{tabular}{|c|c|c|c|c|}
\hline Liability & $\begin{array}{l}\stackrel{D}{I} \\
\overrightarrow{0} \\
\stackrel{D}{D}\end{array}$ & 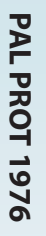 & 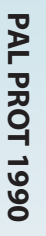 & 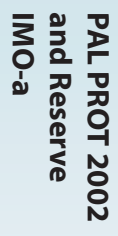 \\
\hline Proven fault & Y & Y & Y & Y \\
\hline $\begin{array}{l}\text { Presumed fault for the shipping incident }{ }^{12} \text { (the burden of proving the absence of fault } \\
\text { lies with the carrier) }\end{array}$ & Y & Y & Y & Y \\
\hline Exemption from liability in the event of passengers' neglect & $\mathrm{Y}$ & Y & Y & Y \\
\hline Liability for the neglect of servants & $\mathrm{Y}$ & Y & Y & Y \\
\hline Limitation of liability of servants & $\mathrm{Y}$ & Y & Y & Y \\
\hline Exemption from liability is not applicable to damage to vehicles due to nautical fault & $\mathrm{Y}$ & $\mathrm{Y}$ & Y & Y \\
\hline Proven fault for the loss of or damage to cabin luggage & $\mathrm{Y}$ & Y & Y & $\mathrm{Y}$ \\
\hline $\begin{array}{l}\text { Presumption of fault for the loss of or damage to cabin luggage caused by a shipping } \\
\text { incident }\end{array}$ & Y & Y & Y & Y \\
\hline $\begin{array}{l}\text { Presumption of fault for the loss of or damage to luggage other than cabin luggage, } \\
\text { irrespective of the nature of the incident }\end{array}$ & Y & Y & Y & $\mathrm{Y}$ \\
\hline $\begin{array}{l}\text { The carrier is not liable for the valuables, except where such valuables have been } \\
\text { deposited with the carrier }\end{array}$ & Y & Y & Y & Y \\
\hline No limitation of liability if the carrier intended to cause the incident & Y & Y & Y & Y \\
\hline 2 year time-bar & $\mathrm{Y}$ & Y & Y & $\mathrm{Y}$ \\
\hline $\begin{array}{l}\text { Liability “Poincare Franc” } \\
700,000 \mathrm{PF}^{13} ; 12,500 \text { PF; } 18,000 \text { PF; 50,000 PF }\end{array}$ & Y & Y & Y & $\mathrm{Y}$ \\
\hline $\begin{array}{l}\text { Special Drawing Rights (SDR) } \\
\text { SDR46,666 }{ }^{14} \text {; SDR833; SDR1,200; SDR3,333 SDR }\end{array}$ & $\mathrm{N}$ & $\mathrm{Y}$ & $\mathrm{N}$ & $\mathrm{N}$ \\
\hline $\begin{array}{l}\text { Special Drawing Rights (SDR) } \\
\text { SDR175,000; SDR1,800; SDR2,700; SDR10,000 }\end{array}$ & $\mathrm{N}$ & $\mathrm{N}$ & $\mathrm{Y}$ & $\mathrm{N}$ \\
\hline Financial guarantee and compulsory insurance & $\mathrm{N}$ & $\mathrm{N}$ & $\mathrm{N}$ & Y \\
\hline $\begin{array}{l}\text { Two tier liability system })^{15} \\
\text { Strict liability - SDR250,000; } \\
\text { Presumed fault up to SDR400,000 }\end{array}$ & $\mathrm{N}$ & $\mathrm{N}$ & $\mathrm{N}$ & Y \\
\hline Limitation of liability per carriage & $\mathrm{Y}$ & $\mathrm{Y}$ & Y & $\mathrm{N}$ \\
\hline Limitation of liability per each distinct occasion & $\mathrm{N}$ & $\mathrm{N}$ & $\mathrm{N}$ & $\mathrm{Y}$ \\
\hline Source: Authors as per Pošpišil-Miler (2014) & & & & \\
\hline
\end{tabular}

12. Shipping incident means shipwreck, capsizing, collision, stranding, explosion, fire, ship defect.

13. The Franc Poincaré is a unit of account that was used in the international regulation of liability. It is defined as 65.5 milligrams of gold of millesimal fineness

14. The Special Drawing Right (SDR) currency value is determined by summing the values in U.S. dollars, based on market exchange rates for major currencies (the U.S. dollar, Euro, Japanese yen, pound sterling and the Chinese renminbi). It is calculated daily (except on International Monetary Fond (IMF) holidays or whenever the IMF is closed for business) and the valuation basket is reviewed and adjusted every five years. On the date of this paper, 1 SDR was equivalent to USD 1.439. At the time of the ratification of the PAL 1974 convention 1 SDR was equal to USD 1.301.

15. A two-tier liability system based on the Montreal Convention, where the carrier is liable on the basis of strict liability for the consequences of a shipping incident, while for further damage the liability of the carrier is based on a system of presumed fault. The amounts are shown in the Table. 
the 1974 Athens Convention and the 2002 Protocol lies in the fact that whereas in the former the liability pertained to the carriage of passengers or luggage irrespective of the number of incidents, in the latter the liability pertains to individual incidents.

\subsection{IMO Reservation and Guidelines and Regulation (EC) $392 / 2009$}

It is a maritime practice for carriers to be insured through P\&l clubs and other commercial insurers. Due to terrorism and war, and the resulting impossibility to rapidly ratify the 2002 Protocol to the Athens Convention, in 2006 the IMO proposed an unusual method of amending the Convention, i.e. the possibility to ratify the Convention with the Reservation and Guidelines. In this way, the IMO Reservation limited the carrier's liability to the lower of SDR250,000 per passenger per incident or SDR340 million overall. Furthermore, the IMO Guidelines oblige states to verify insurance certificates so that one insurer covers nonwar-related risks (compulsory insurance), while another insurer covers war-related risks. Each insurer is liable for its scope of responsibility (Atlija, 2016).

Pursuant to Regulation (EC) No 392/2009 of the European Parliament and of the Council, the provisions of the Athens Convention and the 2006 IMO Reservation and Guidelines became binding with the Convention's entry into force. The aim was to accelerate their implementation, at least in EU member states (Pošpišil-Miler, 2014). The Regulation applies to ships, where:

- the ship is flying the flag of or is registered in a Member State;

- the contract of carriage was concluded in a Member State;

- the place of departure or destination is in a Member State;

- $\quad$ ships perform carriage in non-EU Member States.

Financial security (certificate of insurance) is required to be inspected by the Port State Control when ships call to Paris MoU ports.

It should be noted that Regulation 392/2009 grants passengers the following additional rights:

- $\quad$ the performing carrier shall make an advance payment sufficient to cover immediate economic needs within 15 days on a basis proportionate to the damage suffered. In the event of death, the payment shall not be less than EUR 21,000;

- the carrier shall compensate the costs relating to repairs of mobility equipment;

- the carrier shall ensure that passengers are provided with information regarding their rights prior to the conclusion of the contract of carriage;
- if the contract is not concluded in a Member State, passengers shall be provided with information prior to departure.

Shoreline Ltd. ("Shoreline") provides its Shoreline Passenger Solutions ("SPS") to insure cruise ships and ferries against War Risk, as required under the IMO 2002 Athens Convention and the European Union's Passenger Liability Regulation ("Athens 2002 PLR") (Shoreline, 2021). As evidence of war insurance coverage, and compliance with the Convention and Regulation (EC) No 392/2009, shipowners are required to insure themselves sufficiently to cover and satisfy all claims. The SPS is also available as a reinsurance facility to those $P$ \& I Clubs ("Clubs") who prefer to issue the Blue Card themselves.

\section{RATIFICATION OF THE ATHENS CONVENTION}

Through ratification or in some other way, a state accepts international conventions, and undertakes to prepare its national legislation for the implementation of an international treaty. In accordance with (the Official gazette of the Republic of Croatia) ratification is an international commitment whereby a state indicates its consent to be bound by an agreement. Acceptance, approval, signing, accession and notification of succession are the acts through which the Republic of Croatia gives its consent to be bound by an international treaty. Article 2 sets forth that the Convention shall apply to any carriage if the ship is flying the flag of or is registered in a State Party to this Convention, or the contract of carriage has been made in a State Party to this Convention, or the place of departure or destination, according to the contract of carriage, is in a State Party to this Convention. ${ }^{16}$

States may become parties to this Convention and/or to the Protocol to the Athens Convention (IMO, SOLAS) by:

- signature without reservation as to ratification, acceptance or approval;

- signature subject to ratification, acceptance or approval, followed by ratification, acceptance or approval;

- accession.

This Protocol shall enter into force twelve months following the date on which 10 States have either signed it without reservation as to ratification, acceptance or approval or have deposited instruments of ratification, acceptance, approval or accession with the Secretary-General.

As for the ratification of the Athens Convention, we deem important to mention the original 1974 Convention (PAL 1974) and the 2002 Protocol (PAL PROT 2002).

16. Article 2 Application; Athens Convention Relating to the Carriage of Passengers and their Luggage by Sea, 2002 


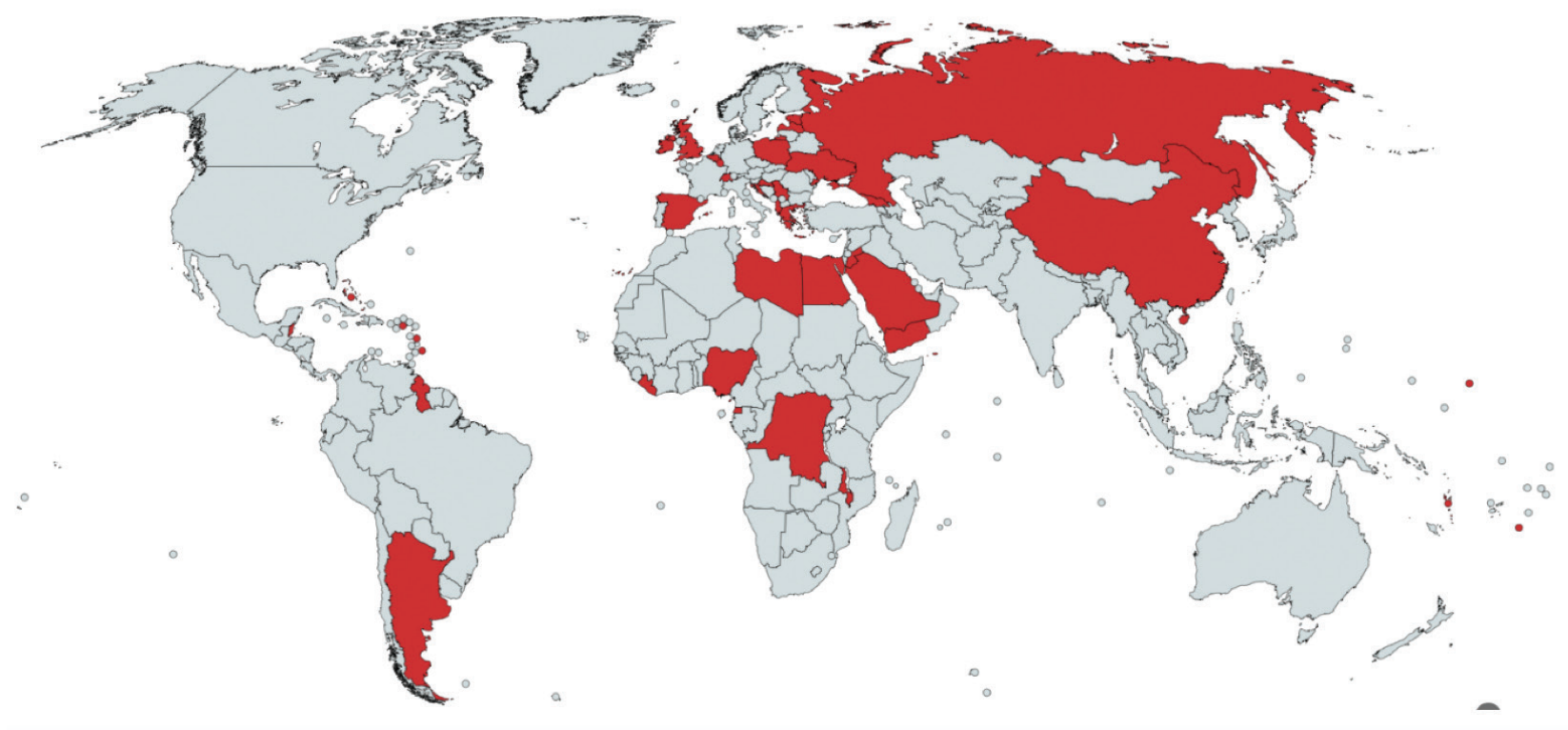

Figure 1.

Countries that ratified the PAL 1974

Sources: Authors, according to data published by the IMO

Figure 1 shows that 25 states acceded to the 1974 PAL Convention, while 13 states denounced the Convention. Argentina, the Federal Republic of Germany and the then USSR became parties to this Convention with reservation to ratification. Pursuant to the final clauses of this Convention, i.e. Article $22^{17}$, paragraph 1, any party may declare that it will not give effect to this Convention when the passenger and the carrier are subjects or nationals of that party. The State of Argentina claimed the territorial sovereignty over the Falkland Islands (Islas Malvinas), which was disputed by the United Kingdom of Great Britain and Northern Ireland, as stated in the text of the Convention. The Convention entered into force on 28 April 1987.

The 1976 Protocol (PAL PROT 1976) entered into force on 30 April 1989. It was signed by 16 member states, while 11 denounced the Convention. Argentina set the accession condition similar to the previous one, while Switzerland, the former USSR and the

17. The final clauses of this Convention would become Articles 17 through 25 of the 2002 Protocol to the Athens Convention relating to the Carriage of Passengers and their Luggage by Sea, 1974. In this Convention, any references to States Parties shall be taken to mean references to States Parties to that Protocol.
United Kingdom of Great Britain and Northern Ireland made the unit of account the Special Drawing Right (Article $9^{18}$ ). The 1990 Protocol (PAL PROT 1990) never entered into force. It was signed by only 3 member states. Egypt was the first signatory country, followed by Spain and the Republic of Croatia ${ }^{19}$, Togo, Albania and Luxembourg.

The 2002 Protocol (PAL PROT 2002) entered into force on 23 April 2014 and was signed by 31 member states.

States that have signed (Figure 2) the last PAL PROT 2002 are not required to be signatories to the previous three protocols (PAL PROT 1974, PAL PROT 1976 and PAL PROT 1990). In addition to the mentioned protocol, it should be emphasized that some countries have set the conditions for accession, such as Belgium, Denmark, Bulgaria, Croatia and several other countries.

18. The Unit of Account mentioned in this Convention is the Special Drawing Right as defined by the International Monetary Fund.

19. Croatia signed the Protocol on 12 January 1998 and denounced it 5 years later. On that same date it signed the accession to the latest protocol (PAL PROT 2002). On the date of denunciation of the previous protocol, 23 April 2014, Croatia joined the latest protocol (PAL PROT 2002). 


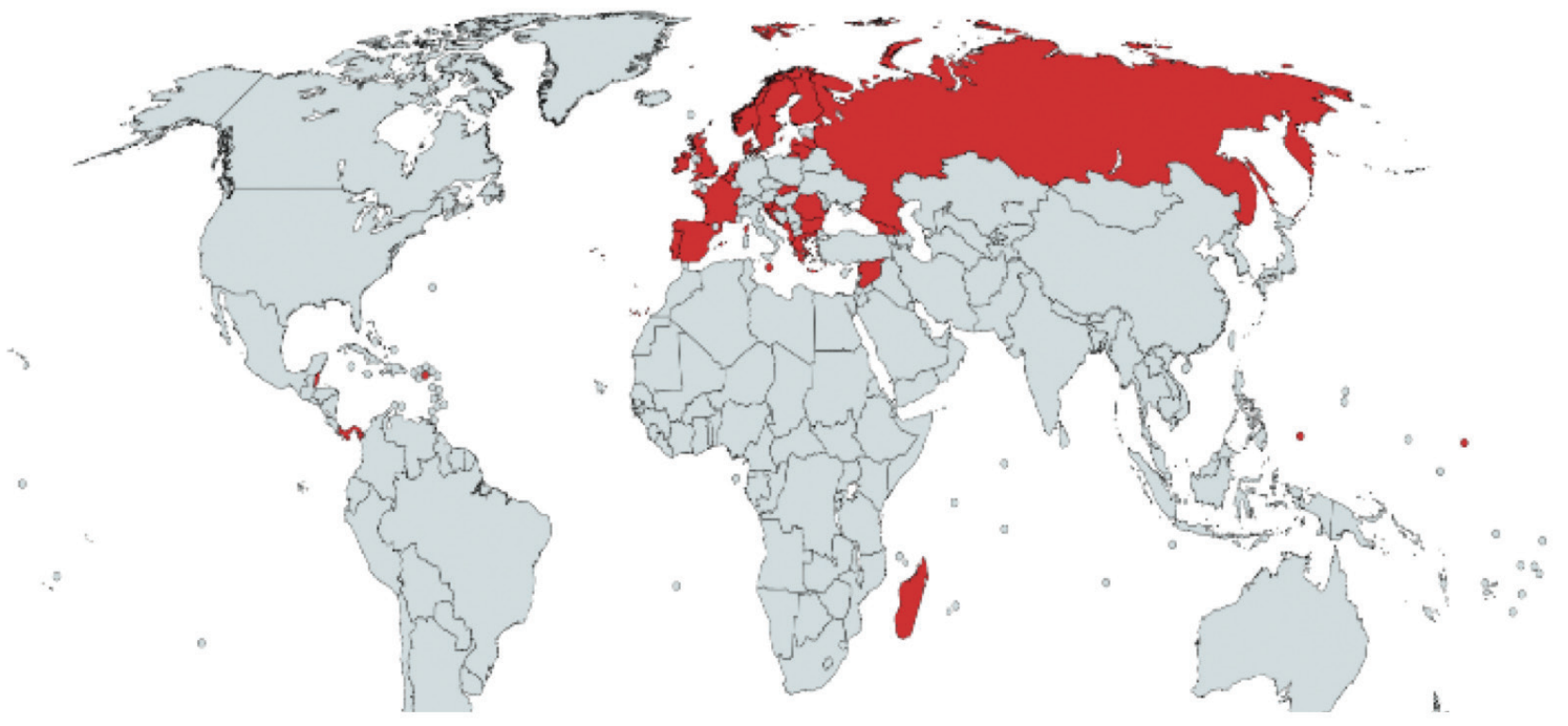

Figure 2.

Countries that ratified PAL PROT 2002.

Sources: Authors, according to data published by the IMO.

Belgium and Bulgaria have set their terms of accession, the so-called mutatis mutandis [muta: 'tis muta'ndis] (lat.) meaning "with things changed that should be changed", which were previously specified by Denmark. They relate to the limits of liability of the carrier, largely to compulsory insurance items, limited liability of the insurer, issuance of a Certification, and relationship between this Reservation and the IMO Guidelines for Implementation of the Athens Convention) (Ćorić, et al. 2011).

Among the Flag of Convenience (FOC) ${ }^{20}$ countries, Malta, the Marshal Islands and Panama signed the Protocol (PAL PROT 2002).

The first two Protocols increased the limitation amounts without significantly affecting the main principles, while the latest Protocol, in addition to increasing the amounts, provides for a strict liability of the carriers, including compulsory insurance, with the right to direct action against insurers (Pospišil-Miler, 2004). However, with respect to the global accession to the Protocol, the major world powers, the United States, China and

20. The term Flag of convenience (FOC) has been in use since 1950. It is a business practice whereby a ship's owners register a merchant ship in a ship register of a country other than that of the ship owner. A ship's owner may elect to register a ship in a foreign country which enables it to avoid the regulations of the owners' country which may, for example, have stricter safety standards, operating costs, higher taxes. Such countries are the Bahamas, Bermuda, Cyprus, the Cayman Islands, Malta, the Marshall Islands, Panama, etc.
Australia, are not signatories to this protocol. In general, the Protocol is mostly acceded to only in Europe, whereas it is either not acceded to at all or on other continents, or is acceded to by a relatively small number of countries.

The latest Protocol, modifying this Convention, states that it is widely accepted in terms of standards, state policy and the needs of the current market. This fact raises the following questions:

What about the states that remain subject to the original 1974 Convention?

- What is the reason for their non-accession to the new protocol?

- Why has the rest of the world not acceded to the Convention, i.e. the Protocol?

- Which new provisions were adopted by the latest protocol?

- How to determine the market-related proportional growth of the limitation amount among developed and less developed countries?

First of all, the changes are evident in the increased limit of carrier's liability, among other things, for the death of or personal injury to a passenger. The initial amounts, indicated in the 1974 PAL, were lower, with a liability limit of SDR 46,666 or USD60,713 for passenger deaths and injuries, compared to the limit of liability of SDR 250,000 or USD359,750 under the latest PAL PROT 2002 Protocol. Such a change within the last Protocol could have 
been anticipated because the amount grew chronologically with the development of the Convention.

Under the Convention (Marin et al., 2011) the carrier ${ }^{21}$ shall be liable unless the incident:

(a) resulted from an act of war, hostilities, civil war, insurrection or a natural phenomenon of an exceptional, inevitable and irresistible character; or

(b) was wholly caused by an act or omission done with the intent to cause the incident by a third party.

The carrier's liability exceeds SDR250,000 if the incident which caused the loss was due to the fault or neglect of the carrier. ${ }^{22}$

This is probably the reason for the rejection of the Convention, especially in countries where transport plays a different political and social role. In countries with many islands that need maritime passenger transportation for communication between the islands and the mainland, transportation is provided by the state or a state-owned company that, for political reasons, offers a minimum ticket price. Many of these companies do not even cover the basic running and maintenance costs. Accordingly, they are unable to supply larger amounts of money, especially for compulsory insurance, which is one of novelties introduced by the last Protocol (Pospišil-Miler, 2004).

Every passenger ship to which PROT PAL 2002 applies and which is registered in a State Party shall have a certificate of insurance or other financial security sufficient to cover the carrier's liability under this Convention for the death of or personal injury to the passengers. The amount is equal to the carrier's liability limit of SDR250,000 per passenger and per incident (PAL 1974). As shipowners and insurers considered this amount too high, they questioned its feasibility in the market (Pospišil-Miler, 2004). Moreover, the newly introduced two-tier liability regime provides for strict liability for damage up to SDR250,000 per passenger and per incident in the event of the death of or personal injury to a passenger caused by a shipping incident. If the damage exceeds the set amount, the maximum amount increases to SDR400,000 per passenger and per incident based on presumed fault. However, if the damage has not occurred as a result of a shipping incident, the basis of proven fault applies, with limited liability of up to SDR400,000 per passenger and event (PAL 1974). Member states are allowed to fix limits of liability higher than those prescribed if they consider them too low (opt-out).

The third novelty would be the option to directly sue the insurer (Milošević-Pujo,2004). This provision is hugely inconvenient for P\&l clubs, since one of their main principles of

21. The carrier shall, in relation to the carriage performed by the performing carrier, be liable for the acts and omissions of the performing carrier and of his servants and agents acting within the scope of their employment.

22. "Fault or neglect of the carrier" includes the fault or neglect of the servants of the carrier, acting within the scope of their employment; "pay to be paid" is contrary to that provision. Namely, previously it was common practice that when an insured shipowner was proven liable for damage caused to a third party, such shipowner would first pay compensation for damage, and only then address the insurer, i.e. the P\&l club that would refund the disbursed amount. There are exceptions to this rule in strictly defined cases determined by international conventions, where direct claims from the clubs are allowed (Faculty of Law, 2021).

\section{APPLICATION OF THE ATHENS CONVENTION}

Looking at the territory of Europe, the Scandinavian countries are not signatories to this convention, but incorporate its liability regime into their domestic law (PAL 1974). Norway has not ratified the convention due to being dissatisfied with the amount of the limits of liability. The liability of carriers is limited under the provisions of the Norwegian Maritime Code, but in the matters of liability in respect to the death of or personal injury to a passenger or the loss of or damage to the passenger's luggage, they comply with the Convention. Norway and other Scandinavian countries, Germany, France and the Netherlands all incorporated the 1974 Convention into their respective legislations but did not ratify it due to their aforementioned dissatisfaction with the limits of liability prescribed by the Convention.

On the other hand, the United States of America (USA) have never acceded to any international maritime convention regulating the liability limitation simply because the U.S. Code does not allow a shipowner to limit his contractual liability to a passenger with respect to personal injury and death. However, occasionally and in special circumstances, their courts have complied with the limits of liability prescribed under this Convention. If the Athens Convention was indicated in a contract of carriage and its amounts were clearly stated, and the vessel was not under a U.S. flag, did not call at a U.S. port, and the incident did not occur in U.S. waters, the courts occasionally complied with such a treaty.

Canada has acted in a similar way in such isolated cases. Although it has not ratified the 1974 Convention, it has introduced into its domestic law a regime of limitation of liability of the Athens Convention incorporated in the 1990 Protocol that prescribed the maximum limit of SDR175,000 for the death of and personal injury to a passenger.

Argentina is specific in that it has ratified the said Convention, but stated that it did not apply if both the passenger and the carrier are their nationals (IMO).

The 2002 Protocol was widely accepted only in Europe, owing to the European Union's commitment to its entry into force. One of the measures taken was a directive to implement the Protocol provisions relating to the liability for the death of and personal injury to a passenger, adopted by the European Commission that consolidated and harmonized these rights. 
The desired outcome was the adoption of the Protocol by the European Union, and its than 15 Member States, which would be a sufficient number of states for its entry into force. Today, the Protocol is implemented in EU regulations 392/200923 and $1177 / 2010^{24}$ and directly applies to Member States, with the aim of creating a coherent legal framework within the European Union, i.e. it allows EU citizens to have access to the same levels of compensation when traveling between EU Member States (EU Claims).

\subsection{The Athens Convention and Directive (EU) $2015 / 2032$}

Due to the increasing use of the Internet for travel service bookings, as opposed to services offered in travel agencies, the Directive 1990/314 had to be adapted to improve the legal safety of travellers and vendors. The 2015/2032 Directive repealed the previous 90/314 Package Travel Directive. This new Directive defines travel services and provides an extended definition of package as a combination of at least two different types of travel services, and sets certain limitations (Atlija, 2016) attempted to resolve the issue of applicable legislation in the event of the death of and personal injury to passengers by proposing that the following questions be asked:

- $\quad$ is it an EU member state;

- if it is an EU member state; does national legislation, together with EU directives, apply if a country formally agreed to be bound by another international treaty?

When implementing EU legislation, it is necessary to ascertain whether domestic or international carriage are in question. For the purposes of this paper, the regulatory regime pertaining to the international carriage will be defined. According to the Athens Convention (Article 14), no action for damages for the death of or personal injury to a passenger shall be brought against a carrier otherwise than in accordance with the Convention. Based on the examples of the case law provided by the author (Atlija, 2016), it is evident that non-compliance with the provisions of the Athens Convention contributes to legal uncertainty. The provisions of the Athens Convention take precedence over national law only in international maritime transport and damages provided for in the Convention. In case of any other form of damage, national legislation, that may or may not have incorporated EU regulations, may apply. The

23. Regulation (EC) No 392/2009 of the European Parliament and of the Council of 23 April 2009 on the liability of carriers of passengers by sea in the event of accidents

24. Regulation (EU) No 1177/2010 of the European Parliament and of the Council of 24 November 2010 concerning the rights of passengers when travelling by sea and inland waterway and amending Regulation (EC) No 2006/2004 legal position of passengers could be improved through the harmonization of provisions of the Athens Convention with the parts of the contracts that are not covered by the Convention, but are covered by Council Directive 90/314/EEC and Directive (EU) 2015/2032. The case of the maritime accident of a cruise ship (Costa Concordia ${ }^{25}$ ) is the best proof of the application of the Convention. Italy was not a signatory to any of the Athens Protocols at the time of the shipping incident. The EU acceded to the 2002 Protocol to the Athens Convention in 2011, and the Convention entered into force in 2014, two years after the shipping incident. Likewise, Regulation (EC) 392/2009 also came into force after the shipping incident. Due to the nature of the said voyage, and given that Italy is a Member State of the European Union (Italian flag, Italian territorial sea, Italian company), the Italian maritime national law could not be applied because it was a cruise and not a contract of carriage. Italian national law, incorporating the provisions of Directive 90/314, was not relevant in this situation because Italy was a party to the CCV Convention that defines such cruises as organized travels (referred to as packages in Directive 90/314). An international treaty takes precedence over Italian national law for reasons identical to those that justify the application of the Athens Convention to the States that are parties to it. Thus, the provisions of the CCV Convention should apply to the case of Costa Concordia (Atlija, 2016).

\section{DEVELOPMENT STRATEGY PROPOSAL}

The development strategy proposal is the wider ratification of the Convention by countries that have not yet done so. Economic problems and the level of economic development of countries, their geopolitical location and share in the passenger transportation fleet are the main obstacles. The strategy of global acceptance can be ruled out, as measures that increase the amount do not affect all countries equally (e.g. the Flag of Convenience countries (FOC)). Differing shares of countries in the passenger transportation industry do not put all members on an equal footing. Most European countries have acceded to the latest Protocol. It is possible for a working group to recognize the European Union as a tool for broader accession to the Convention, which would be the basis and impetus for further processes. From the perspective of the cruise industry, the focus can be expected to be on the European countries, China, the USA and Australia which are predominant in terms of ports of departure and destination, share of passengers, and destinations. Based on these three novelties - higher limitation amounts, compulsory insurance and a direct suit against the insurer - we can conclude

25. http://www.stige.co.uk/public/gestionesito/files/Diritto\%20e\%20trasporti\%20 Costa\%20Concordia.pdf 
that they all benefit the passengers, which is a positive sign, given that passengers are in the focus of the Convention. However, these provisions have complicated the activities of carriers and insurers, and placed a significant financial burden on them. One provision in particular is problematic - the provision prescribing the increased limitation amount. Namely, potential signatory states differ in fleet size and economic strength, which is best reflected in the difference between average wages and the value of the currency depending on the region. Consequently, determining an amount that would be feasible for third world countries, while simultaneously being high enough for more developed countries is difficult.

Each protocol brought increasing amounts favoured by highly developed countries which demanded their increase, while at the same time being unacceptable to those to which even the initial amounts were too high. This growth trend implies that the working group that drafted the Protocol primarily focused on developed, mostly European countries. It is interesting that China, which has a large cruise market share, both in terms of destination and cruise passenger volume, did not ratified a single protocol since 1974 . The reason for this lies in the fact that China is one of those aforementioned countries for which maritime transport plays a different political and social role, and are accordingly not open to increases in the limitation amount. Furthermore, with respect to the 2002 Protocol, the new compulsory insurance provision imposes an additional financial burden on the subjects, further complicating ratification. The question of the strategy behind the latest protocol remains unanswered. The increased amounts indeed go in favour of the more developed countries, in this case Scandinavian, thus expanding their scope within Europe, but as for the rest of the world nothing significant has been achieved.

Table 2.

SWOT analysis of the PAL PROT 2002 according to passengers, shipping industry, and states.

\begin{tabular}{|c|c|c|c|}
\hline \multirow[t]{4}{*}{ Strengths } & $\begin{array}{l}\text { Limitation period for lawsuits extended } \\
\text { to } 5 \text { years }\end{array}$ & Weaknesses & Speed of ratification \\
\hline & $\begin{array}{l}\text { Claim brought directly against the } \\
\text { insurer }\end{array}$ & & $\begin{array}{l}\text { The large number of clauses of the } \\
\text { Convention, especially the opt-out } \\
\text { clauses }\end{array}$ \\
\hline & $\begin{array}{l}\text { Claim for compensation covered by } \\
\text { financial security }\end{array}$ & & Acceptance of the limits of liability \\
\hline & $\begin{array}{l}\text { Proof of financial security with an } \\
\text { appropriate certificate and uniformity of } \\
\text { the amount of liability }\end{array}$ & & $\begin{array}{l}\text { Keeping records of passengers for a } \\
\text { period of } 5 \text { years }\end{array}$ \\
\hline \multirow[t]{3}{*}{ Opportunities } & $\begin{array}{l}\text { Improved passenger security } \\
\text { (supervision of insurance companies) }\end{array}$ & Threats & $\begin{array}{l}\text { Potential increase in the price of travel } \\
\text { tickets (market instability) }\end{array}$ \\
\hline & Uniformity of legislation & & $\begin{array}{l}\text { Possibility that ships will divert to } \\
\text { countries that did not accede to the } \\
2002 \text { Protocol }\end{array}$ \\
\hline & $\begin{array}{l}\text { Better understanding of passenger rights } \\
\text { on passenger ships }\end{array}$ & & $\begin{array}{l}\text { Double insurance and dissatisfaction of } \\
\text { P\&l clubs, banks and insurers }\end{array}$ \\
\hline Source: Authors & & & \\
\hline
\end{tabular}

SWOT analysis was conducted for purposes of devising a development strategy. The greatest protection of passengers and their rights was brought by the Athens Convention, or more precisely by the 2002 Protocol. It is noticeable that an increasing number of countries opt for any form of ratification of the said convention. The strength of the Convention is the extended time within which a claimant can file a lawsuit directly against the insurer. Another strength is the easier payment of claims to the successful parties in lawsuits due to the provision pertaining to financial security. The weakness of the faster ratification of the Convention is the limit of liability and the liability itself. Some countries argue for unlimited liability, while others are satisfied with the limits. Accessions to the Convention were intended to be facilitated by the incorporated clauses. Keeping records and administrative costs can burden the carrier and create additional costs. Digitalization would reduce such costs. Passenger safety should increase owing to improved insurance company supervision prior to granting a financial guarantee. The legislation 
of the member states that acceded to the Convention would be consolidated, and passengers would be better acquainted with their rights. Threats are an indispensable factor in SWOT analysis. They include increased travel prices, the possibility of market diversion and increased costs resulting from double insurance by both the P\&I clubs and by the financial guarantee. P\&I Clubs, banks and insurers could increase their premiums.

The world's leading travel companies have an immense influence on the ratification process. According to the 2018 reports, Royal Caribbean Limited $\left(\mathrm{RCL}^{26}\right)$, which operates 6 ships in Australian waters, stated to the Australian government that the potential ratification of the Convention, i.e. the 2002 Protocol, was not a step forward compared to the existing system where passenger rights were already guaranteed and that they could therefore not uphold its implementation. A similar view was expressed by Carnival Australia ${ }^{27}$, with a neutral stand on the final decision (Claims for Passenger Injury..., 2020). Carnival Australia is liable under Australian regulations. Given their views, it is arguable whether Australia will join the other signatory countries in the near future. Accordingly, let us assume that the current system applied in a country is at a satisfactory level. The question is whether it is worth changing it and entering into a complicated administrative work if in the end no greater results would be achieved. The answer would probably be NO! Although the Convention offers the consolidation for as many states as possible, it does not necessarily mean that it provides a better legal and business background for both parties to this relationship.

\section{CONCLUSION}

The Athens Convention, with its latest 2002 Protocol, provides legal protection to passengers in case of death and personal injury. When analysing the procedures and speed of ratification, the most important part of the Convention are provisions that regulate the limits of the carrier's liability for the death and injury of passengers, and the manner in which the carrier's fault is proved. From the perspective of a passenger who suffered personal injury during transport, this segment is utterly important as it is closely related to their claims against the carrier to get some kind of compensation. Therefore, any passenger

26. Royal Caribbean Limited (RCL) operates three brands Royal, Celebrity and Azamara Cruises and with more than 40 ships it is the 2nd largest cruise company in the world. Downloaded from: https://www.infrastructure.gov.au/maritime/business/ liability/files/Royal-Caribbean-Athens-Convention-Submission.pdf

27. Carnival Australia is part of the world's largest leisure company, Carnival Corporation \& plc, and represents seven leading cruise brands on the Australian and New Zealand market: Carnival Cruise Line, Cunard Line, Holland America Line, P\&O Cruises Australia, P\&O Cruises World Cruising, Princess Cruises and Seabourn. Downloaded from: https://www.infrastructure.gov.au/maritime/business/ liability/files/Carnival-Australia-Athens-Convention-Submission.pdf who is subject to this Convention should be acquainted with the most important provisions concerning passenger rights. They are available within the contract of carriage or at the websites of travel companies and agencies. When drafting the Protocol, and especially at the conference addressing the Protocol, the shipping industry and insurers pointed out that the Protocol would not be easy to apply in practice owing to the extremely high limits and other strict requirements pertaining to the liability of carriers. Different reactions came from different parties. The opinions and perspectives regarding its ratification and entry into force were diametrically opposed. The European Union thought that its entry into force could be achieved at short notice, stating within a week of the Protocol's adoption that its provisions were in line with the European Union guidelines on maritime passenger transportation from March 2002. The development strategy and the SWOT analysis presented in the paper can contribute to the speed of ratification of the Convention and its Protocol. It is necessary to emphasize the importance of EU regulations and their application in cases of claims for compensation against the carrier. The Athens Convention should be implemented in the states that have ratified it irrespective of special provisions incorporated in their national regulations. When drawing up their contracts of carriage, carriers should emphasize that their provisions are in line with the Athens Convention in order to protect themselves before international courts. The ratification of the Athens Convention is of utmost importance due to the unification of maritime law at the international level.

\section{REFERENCES}

Atlija, I., 2016. Odgovornost za smrt i tjelesne ozljede putnika u kružnom putovanju (Cruising), Zagrebačka pravna revija, 5(3), pp. 325-362. Available at: https://hrcak. srce.hr/196264.

Claims for Passenger Injury and Damage to Luggage, 2020. Government of Australia. Available at: https://www.infrastructure.gov.au/maritime/business/ liability/damage luggage.aspx, accessed on: October 2020.

CLIA, 2018. Global Passenger Report 2018. Available at: https://cruising.org/-/ media/research-updates/research/clia-global-passenger-report-2018.pdf.

CLIA, 2019. Review Cruise Trends \& Industry Outlook 2019. Available at: https:// cruising.org/news-and-research/-/media/CLIA/Research/CLIA-2019-State-of-theIndustry.pdf.

CLIA, 2020. Passenger Bill of Rights. Available at: https://www.crystalcruises.com/ legal/clia-passenger-bill-of-rights, accessed on: December 2020.

Ćorić, D. et al., 2011. IMO rezerva i smjernice za primjenu Atenske konvencije : (prijevod). Poredbeno pomorsko pravo, 50 (165), pp. 362-383. Available at: https:// hrcak.srce.hr/77066.

Directive (EU) 2015/2302 of the European Parliament and of the Council of 25 November 2015 on package travel and linked travel arrangements, amending Regulation (EC) No 2006/2004 and Directive 2011/83/EU of the European Parliament and of the Council and repealing Council Directive 90/314/EEC, 2015 OJ L 326.

European Union: The Revised Athens Convention: Strict Liability And Higher Limits 
Of Liability For Passenger Claims, 2020. Available at: https://www.mondaq.com/ uk/Transport/307562/The-Revised-Athens-Convention-Strict-Liability-And-HigherLimits-Of-Liability-For-Passenger-Claims, accessed on: October 2020

Faculty of Law, 2020. Homepage, University of Zagreb. Available at: https://www. pravo.unizg.hr/POP/predmet/pop_a/studenti_pitaju/aktualna_pitanja/pi_klubovi.

IMO home page, 2020. Available at: https://wwwcdn.imo.org/localresources/en/ About/Conventions/StatusOfConventions/Status\%20-\%202020-Sep.pdf, accessed on: June 2020

IMO, 2020. Status of IMO treaties. Available at: http://www.imo.org/en/About/ Conventions/StatusOfConventions/Documents/Status\%20-\%202020.pdf, accessed on: September 2020

International Maritime Organization (IMO), 1974. SOLAS, International Convention for the Safety of Life at Sea, London: International Maritime Organization.

Lamont-Black, S., 2018. Sea Passenger Rights and the Implementation of the Athens Convention in the EU. SSRN Electronic Journal. Available at: http://dx.doi.org/10.2139/ssrn.3256773.

Marin, J., Padovan, A.V. and Mudrić, M., 2011. Atenska konvencija o prijevozu putnika i njihove prtljage morem, 2002. : (prijevod). Poredbeno pomorsko pravo, 50 (165), pp. 310-361. Available at: https://hrcak.srce.hr/77065.

Milošević-Pujo, B., 2004. The Contract of Carriage of Passengers and their Luggage by Sea, Basic Features, Zbornik radova Pravnog fakulteta u Splitu, 73-74, pp. 87-96.

Official gazette, 1993; of The Republic of Croatia, Convention ratification. Available at: https://narodne-novine.nn.hr/clanci/medunarodni/1993 1216 37.html.

Pospišil-Miler, M., 2004. Atenska konvencija o prijevozu putnika i njihove prtljage morem 2002. Godine, Poredbeno pomorsko pravo, 43(158), pp.227-262. Available at: https://hrcak.srce.hr/41979.
Pošpišil-Miler, M., 2014. New liability Regime for death and personal injuries of passengers in maritime transport, Pravni fakultet Sveučilišta u Rijeci.

Regulation (EC) No 392/2009 of the European Parliament and of the Council of 23 April 2009 on the liability of carriers of passengers by sea in the event of accidents 2009 OJ L 131

Regulation (EU) No 1177/2010 of the European Parliament and of the Council of 24 November 2010 concerning the rights of passengers when travelling by sea and inland waterway and amending Regulation (EC) No 2006/2004 OJ L 334.

Šamanović, J., 2002. Nautički turizam i menadžment marina, Visoka pomorska škola u Splitu.

Seatrade Cruise News, 2020. Available at: https://www.seatrade-cruise.com/ downloads/updated-seatrade-cruise-orderbook, accessed on: October 2020.

Seatrade Cruise Review, 2020. Available at: https://cloud.3dissue. com/176015/176412/205860/SCR0920/index.html?r=71, accessed on: December 2020.

Shoreline, 2020. Passenger Solutions. Available at: https://www.shoreline.bm/ solutions/passenger-solutions/.

The 1974 Athens Convention relating to the Carriage of Passengers and their Luggage by Sea and the 2002 Protocol, A study concerning the Shipowner's right to Limitation of Liability; available at: https://www.duo.uio.no/bitstream/handle/10852/20434/ AthensxConventionxandxthex2002xProtocolx--xAxStudyxonxLiablityxLimitation. pdf? sequence $=1$ \&isAllowed $=\mathbf{y}$.

Ward, D., 2018. Berlitz Cruising and Cruise Ships. Rough Guides UK, ISBN:1785730789, 9781785730788 .

Zec, D., 2001. Sigurnost na moru, Rijeka, ISBN: 953-165-077-2. 